Original Paper http://ajol.info/index.php/ijbcs http://indexmedicus.afro.who.int

\title{
Simple and multiple linear regressions between oil palm annual yields and yearly climatic variables over a 23-year-period (1990-2012) in the coastal zone of Cameroon
}

\author{
Fidèle $\mathrm{NKODO}^{1 *}$ and Zachée $\mathrm{AMBANG}^{2}$ \\ ${ }^{I}$ Department of Agriculture, FAAS, University of Dschang, Po. Box 6978 Yaoundé, Cameroon. \\ ${ }^{2}$ Department of Plant Biology, Faculty of Sciences, University of Yaoundé I, Po. Box 812 Yaoundé, Cameroon. \\ *Corresponding author, E-mail: fidelenkodo956@yahoo.fr, Zachambang@yahoo.fr; \\ Phone: (+237) 699197115 or (+237) 675770095 .
}

\begin{abstract}
This study was aimed at determining whether variations in oil palm annual yields were significantly influenced by years of production, and at establishing if so simple and multiple linear regression relationships between oil palm annual yields and yearly climatic variables. Climatic and yield data were gathered in three locations (Bota-Limbe, Dizangué and Kienké) of the coastal zone of Cameroon, within the oil palm estates of three agro-industrial corporations. Yearly climatic variables were recorded for a period of 23 consecutive years (1990-2012); oil palm annual yields of five plots in each location were also recorded for the same period. Variations in annual yields (in metric-tons of bunches per hectare) were significantly influenced $(\mathrm{P}<0.05)$ by years of production. Only a few yearly climatic variables however were significantly correlated with annual yields (none of the climatic variables in Bota-Limbe; evapotranspiration and rainfall height in Dizangué and insolation in Kienké). Low but significant, simple and multiple linear regressions were established that contributed to explain 18.10 to $54.60 \%$ of annual yields. Other mathematical relationships for more accurate predictions must be built, as for example curvilinear regressions; for linear regressions may not be sufficient to explain annual yields in their completeness.

(c) 2015 International Formulae Group. All rights reserved.
\end{abstract}

Keywords: Evapotranspiration, insolation, rainfall height, variations, predictions, mathematical relationships.

\section{INTRODUCTION}

Oil palm (Elaeis guineensis Jacq.) is commercially grown within the space ranging between $15^{\circ}$ of latitudes in either sides of the equator (Corley, 2001; Corley and Tinker, 2003). Cameroon exploits oil palm on its coastal zone, in particular where that exploitation is carried out intensively within vast plantations of several thousands of hectares (Bell, 2006).
The oil palm surface areas globally exploited by Cameroonian agro-industrial corporations have remained quite unchanged; around 100,000 ha during last decades. However, yields on the same surface areas have always fluctuated considerably year-onyear; between 120,000 and 200,000 metrictons of crude palm oil (Anonyme, 2001).

Such important and recurrent variations in palm oil yields make the producing 
enterprises accounts and the related state funds less stable (the State depends somewhat on currencies generated by palm oil production). Moreover, the populations experience a palm oil shortage in times of low supply; consequently, prices rise on the domestic market. During years of overproduction, in the other hand, the sale at lost usually due to domestic and international saturated markets provokes low revenues for the producing enterprises and for the State; with in addition supplementary costs for the producing enterprises due to the storage of unsold goods (Nkodo, 2014).

Studies on that phenomenon of yield variations, which can be seen year-on-year on the same plantations, have led many researchers to blame the climate; notably on fluctuating factors such as rainfall, air relative humidity, insolation and temperature (Henson and Mohd Tayeb, 2004; Henson, 2007). The current study was aimed at determining the effect of year, that is to say the effect of annual climate on palm oil yield; and at establishing simple or multiple linear regression relationships between oil palm yields (in metric-tons of annual bunches per hectare) and yearly climatic variables.

\section{MATERIALS AND METHODS}

\section{Study area}

The study was carried out using data of three industrial oil palm plantations located in the coastal zone of Cameroon; at CDC (Cameroon Development Corporation) in Bota-Limbe, at SAFACAM (Société Africaine Forestière et Agricole du Cameroun) in Dizangué and at SOCAPALM (Société Camerounaise des Palmeraies) in Kienké. The coastal zone of Cameroon is globally located between latitudes $4^{\circ} 00^{\prime}-6^{\circ} 30^{\prime}$ North and longitudes $8^{\circ} 30^{\prime}-10^{\circ} 00^{\prime}$ East. It is a land strip of about $50 \mathrm{~km}$ wide (between the Atlantic Ocean and the interior of the national territory) and about $400 \mathrm{~km}$ long (from the
Nigerian border north of the Akwayafe River to the Equatoguinean border south of the Campo River). The map of the study area is provided (Figure 1). That zone of about $55,000 \mathrm{~km}^{2}$ extends from north to south on three administrative regions (South-west, Littoral and South) in which live close to $2,700,000$ inhabitants; thus $15 \%$ of the population (Anonyme, 2010).

The coastal zone made of plains and plateaus is at an altitude of $0-300 \mathrm{~m}$. The climate is typically Equatorial or Guinean; it changes progressively north to south from a one-mode rainfall pattern (with a single dry season and a single rainy season) to a twomode rainfall pattern (with two dry seasons and two rainy seasons). Soils are also diverse; they were born on sea sediments or on volcanic elements, or on ferralitic soils, etc. (Akoua, 2005; Mvondo-Ze, 2008; Nkoume, 2011; Bassogog, 2013). Mostly acid, very poor in nutrients, these soils are of a low agricultural value and are used for oil palm or rubber cropping (Anonyme, 2007; JulienFrançois, 2008). The natural vegetation is characterized by appearances ranging from secondary forest to evergreen forest, with from places to places, on marshy soils along rivers, patches of lowland Atlantic forest bearing multiple stilt trees (Yana, 2008).

\section{Methodology}

Most climatic data were obtained at the Direction of Agricultural Services of each agro-industrial corporation concerned. Supplementary climatic data were found in near-by National Weather Services; in particular at the Weather Station of Kribi for Kienké and at the Direction of Weather of Littoral in Bonandjo-Douala for Dizangué. Exploiting monthly weather forecasts from ARID (Agricultural Research Institute for Development) in Dibamba was also helpful in completing some climatic data for Dizangué. All climatic data for Bota-Limbe were 


\section{F. NKODO and Z. AMBANG /Int. J. Biol. Chem. Sci. 9(6): 2833-2846, 2015}

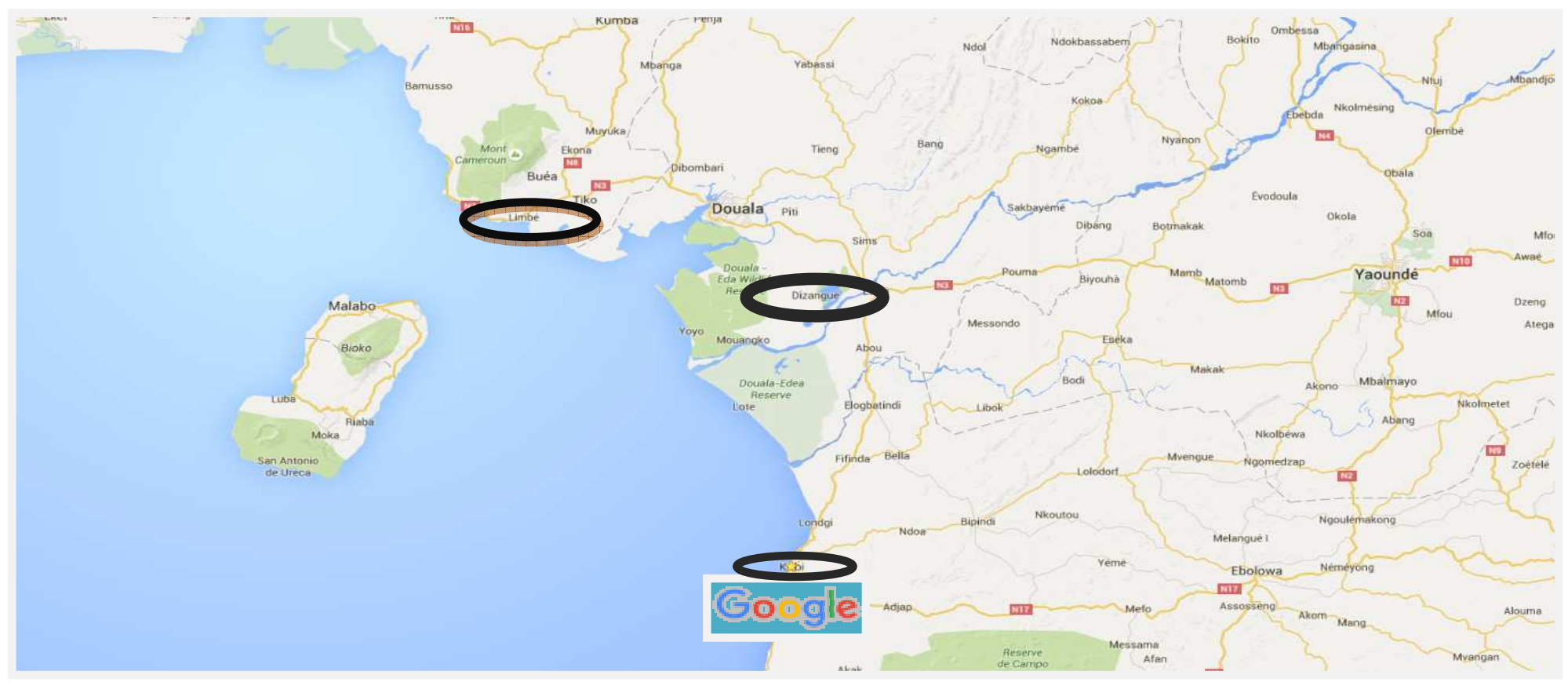

Figure 1: Map of the study area (The 3 locations of data collection are circled). Source: Google Map (2012) 
provided by CDC; either at the Agricultural Services of various oil palm estates or at the Headquarters in Bota.

Consulting several annual reports of activities from the agro-industries concerned has enabled to get data on oil palm yields. When collecting oil palm yields, care was taken to consider only field plots of more than 10 years of age, to avoid introducing bias sources in the statistical analyses. Before the age of ten, as a matter of fact, oil palms show a continuous increase in yields that stabilizes only after that period. The annual yields of each location were calculated using the average annual yields of five field plots (which were not necessarily of the same size); these field plots were dispersed within each of the three locations under study.

\section{Data collection and analysis}

Yearly climatic variables concerning solar radiation received (SR) or insolation, minimum temperature $\left(T_{\text {min }}\right)$, maximum temperature $\left(T_{\max }\right)$, mean temperature $\left(T_{\text {mean }}\right)$, minimum relative humidity $\left(\mathrm{RH}_{\min }\right)$, maximum relative humidity $\left(\mathrm{RH}_{\max }\right)$, mean relative humidity $\left(\mathrm{RH}_{\text {mean }}\right)$, height of rainfall $\left(\mathrm{R}_{\mathrm{mm}}\right)$, days of rainfall $\left(\mathrm{R}_{\text {days }}\right)$, evapotranspiration (ETP) and water deficit (WD) were recorded for a period of 23 consecutive years (1990-2012); oil palm annual yields (in metric-tons of bunches per hectare) of five field plots in each site were also recorded for the same period.

An analysis of variance (ANOVA) was carried out to show the existence of significant differences between annual oil palm yields. A separation of means was done using the Least Significant Difference method. A search of significant correlations between oil palm annual yields and yearly climatic variables was done and simple or multiple linear regressions were established. The SPPS 20 software was used for data analysis and the EXCEL version 2007 software was used to build tables and draw graphs.

\section{RESULTS}

\section{Year effect on oil palm yields}

Variations in annual oil palm yields (expressed in metric-tons of bunches per hectare) over a 23-year-period (1990-2012) in the three locations of the coastal zone were confronted against each other (Figure 2). It comes out that oil palm annual yields have fluctuated considerably during the period observed. During that period, Dizangué had the highest yields in general; revealed by a mean of 13.092 metric-tons of bunches/ha/year, with a standard-deviation (SD) of 1.732 metric-tons of bunches/ha/year and a coefficient of variation (CV) of $13.23 \%$; Kienké had yields next to the highest with a mean of 11.691 metric-tons of bunches/ha/year, a SD of 1.141 metricton/ha/year and a CV of $9.76 \%$; and BotaLimbe had the lowest yields with a mean of 9.905 metric-tons of bunches/ha/year, a SD of 0.873 metric-ton of bunches/ha/year and a CV of $8.81 \%$. In the overall, oil palm annual yields have fluctuated between 8 and 17 metric-tons of bunches/ha.

The ANOVA of the effects of years, locations and field plots on oil palm annual yields was carried out (Table 1). The F test showed that the main factors (years, locations and field plots) as well as their interactions (years*locations, years*field plots and locations:field plots) all had a very significant effect $(\mathrm{P}<0.01)$ on oil palm annual yields over the period observed (1990-2012).

The separation of means of oil palm annual yields in Bota-Limbe, Dizangué and Kienké in one hand and for the whole three locations in the other hand is emphasized in Table 2. The Least Significant Difference method was used to separate the means.

There was therefore a year effect, probably expressing itself by climatic factors 
which acted during that year, on oil palm production in the coastal zone. However, effects equally highly significant of locations and field plots, as well as their interactions, make one believe other annual factors than the climate have had an influence on the determination of annual oil palm yields.

\section{Significant correlations between oil palm} annual yields and yearly climatic variables

The statistical analysis has revealed that no climatic variable during the period observed (1990-2012) was significantly correlated $(\mathrm{P}<0.05)$ with the annual tonnage of bunches per hectare in Bota-Limbe. No simple linear regression relationship could therefore be established.

Two climatic variables during the same period were significantly correlated $(\mathrm{P}<0.05)$ with annual tonnage of bunches per hectare in Dizangué; it was ETP $(\mathrm{r}=0.426)$ and $\mathrm{R}_{\mathrm{mm}}$ $(\mathrm{r}=0.427)$.

Only one climatic variable over the period was very significantly correlated $(\mathbf{P}<0.01)$ with annual tonnage of bunches per hectare in Kienké; it was SR $(r=0.597)$.

Likewise, only two climatic variables were significantly correlated $(\mathrm{P}<0.05)$ with annual tonnage of bunches per hectare; they were $\mathrm{SR}(\mathrm{r}=-0.431)$ and $\mathrm{R}_{\mathrm{mm}}(\mathrm{r}=0.461)$.

To summarize, ETP, $R_{\mathrm{mm}}$ and SR are the only climatic variables that were proven to be significantly (or very significantly) correlated with annual tonnage of bunches per hectare over the 23-year-period (1990-2012) in the locations investigated on the coastal zone.

Fluctuations of annual ETP in the three locations over the period considered (19902012) were confronted against each other (Figure 3). It comes out that annual ETP has fluctuated considerably. Bota-Limbe had annual ETP next the highest; revealed by a mean of $1026.0 \mathrm{~mm}$, with a SD of $470.7 \mathrm{~mm}$ and a $\mathrm{CV}$ of $45.87 \%$ ); Dizangué had the highest annual ETP with a mean of 1509.8 $\mathrm{mm}$, a SD of $374.5 \mathrm{~mm}$ and a CV of $24.80 \%$; and Kienké had the lowest annual ETP with a mean of $501.8 \mathrm{~mm}$, a SD of $91.6 \mathrm{~mm}$ and a CV of $18.26 \%$.

Bota-Limbe had $1661 \mathrm{~mm}$ in the year with the highest ETP (1990) against $121 \mathrm{~mm}$ in the year with the lowest ETP (1999). BotaLimbe's ETPs dropped particularly between 2001 and 2006. Dizangué had $2229 \mathrm{~mm}$ in the year with the highest ETP (1999) against $807.9 \mathrm{~mm}$ in the year with the lowest ETP (2010). Kienké had $666.9 \mathrm{~mm}$ in the year with the highest ETP (1998) against $371.7 \mathrm{~mm}$ in the year with the lowest ETP (1991).

Fluctuations of annual rainfall $\left(\mathrm{R}_{\mathrm{mm}}\right.$ in the three locations over the period observed (1990-2012) were confronted against each other (Figure 4). It comes out $R_{m m}$ has fluctuated considerably. Bota-Limbe had the lowest $\mathrm{R}_{\mathrm{mm}}$; revealed by a mean of 1980.2 $\mathrm{mm}$, with a SD of $859.9 \mathrm{~mm}$ and a CV of $43.42 \%$; Dizangué had the highest $\mathrm{R}_{\mathrm{mm}}$ with a mean of $2868 \mathrm{~mm}$, a SD of $397.2 \mathrm{~mm}$ and a $\mathrm{CV}$ of $13.85 \%$; and Kienké had $\mathrm{R}_{\mathrm{mm}}$ next the highest with a mean of $2370.2 \mathrm{~mm}$, a SD of $431.9 \mathrm{~mm}$ and a CV of $18.22 \%$. Dizangué recorded the year with the highest $R_{m m}$ (3549.3 $\mathrm{mm}$ in 1995), Bota-Limbe recorded the year with the lowest $R_{m m}(425 \mathrm{~mm}$ in 2004). As it was previously noticed in Figure 3 with the ETPs, Bota-Limbe's rainfalls also dropped particularly between 2001 and 2006 .

Fluctuations of annual insolation (SR) over a 23-year-period (1990-2012) in the three locations investigated in the coastal zone were confronted against each other (Figure 4). It comes out that annual SR has also fluctuated in the three locations. Bota-Limbe had an annual SR next the highest with a mean of 1310 hours, a SD of 234.8 hours and a CV of 17.92\%; Dizangue had the lowest annual SR with a mean of 1228 hours, a SD of 195.4 hours and a CV of $15.91 \%$; and Kienké had the highest annual SR with a mean of 1917.8 
hours, a SD of 375.4 hours and a CV of $19.57 \%$. Over the period, Kienké recorded the highest annual SR (3135.1 hours in 1992) and Bota-Limbe recorded the lowest annual SR (750 hours in 2004).

\section{Simple linear regressions between oil palm} annual yields and yearly climatic variables

The analysis of simple linear regression relationships $(\mathrm{Y}=\mathrm{aX}+\mathrm{b})$ was carried out only for yearly climatic variables $\mathrm{X}$ significantly (or very significantly) correlated with $\mathrm{Y}$ (in annual tonnage of oil palm bunches per hectare).

In Bota-Limbe's case, no simple linear regression relationship could be established.

In Dizangué's case, ETP contributed to explain only $18.10 \%$ of oil palm annual yields with the prediction equation $\mathrm{Y}=0.002 \mathrm{ETP}+10.119$. Just as $\mathrm{R}_{\mathrm{mm}}$ contributed to explain only $18.20 \%$ of oil palm annual yields with the prediction equation $\mathrm{Y}=$ 0.001 $\mathrm{R}_{\mathrm{mm}}+7.750$. Nevertheless, both relationships were significant $(\mathrm{p}=0.043$ and $\mathrm{p}=0.042$ respectively).

In Kienké's case, SR contributed to explain $35.60 \%$ of oil palm annual yields by the prediction equation $\mathrm{Y}=-0.001 \mathrm{SR}+15.171$. The relationship was significant $(\mathrm{p}=0.003)$.

Simple linear regression relationships between oil palm annual yields (in metric-tons of bunches/ha/year) on the one hand and annual ETP and annual $\mathrm{R}_{\mathrm{mm}}$ respectively on the other hand in Dizangué are illustrated in Figures 6 and 7.

A simple linear regression relationship between oil palm annual yields and annual SR in Kienké is illustrated in Figure 8.

In case of a potential location " $\mathrm{x}$ " in the coastal zone whose yield data were built using those from some other known locations (here for instance yield data from Bota-Limbe,
Dizangue and Kienké), only annual SR and annual $\mathrm{R}_{\mathrm{mm}}$ were significantly correlated ( $\mathrm{r}=-$ 0.431 and $r=0.461$ respectively). Annual SR contributed to explain $18.50 \%$ of annual yields with the prediction equation $\mathrm{Y}=$ $0.001 \mathrm{SR}+13.778$ and annual $\mathrm{R}_{\mathrm{mm}}$ contributed to explain $17.50 \%$ of annual yields with the prediction equation $\mathrm{Y}=0.001 \mathrm{Rmm}+8.360$. Both relationships were significant $(\mathrm{p}=0.040$ and $\mathrm{p}=0.027$ respectively).

Simple linear regression relationships between oil palm annual yields on the one hand and annual $\mathrm{SR}$ and annual $\mathrm{R}_{\mathrm{mm}}$ respectively on the other hand for a potential location " $x$ " in the coastal zone are illustrated in Figures 9 and 10.

\section{Multiple linear regressions between oil palm annual yields and yearly climatic variables}

Concerning Bota-Limbe and Dizangué, no significant multiple linear regression relationship could be established in either locations between oil palm annual yields and part or totality of yearly climatic variables.

Concerning Kienké, the multiple linear regression relationship built between $\mathrm{Y}$ (in metric-tons of bunches/ha/year) and three yearly climatic variables ( $\mathrm{SR}, \mathrm{T}_{\max }$ and $\mathrm{T}_{\text {mean }}$ ) contributed to explain $54.60 \%$ of oil palm annual yields with the prediction equation $\mathrm{Y}=-$ $0.02 \mathrm{SR}+0.255 \mathrm{~T}_{\max }-0.020 \mathrm{~T}_{\text {mean }}+7.883$. That relationship happens to be very significant ( $\mathrm{p}=0.002)$.

Concerning finally a potential location " $\mathrm{x}$ " of the coastal zone, no significant multiple linear regression relationship could be established between $\mathrm{Y}$ oil palm annual yields and part or totality of yearly climatic variables. 


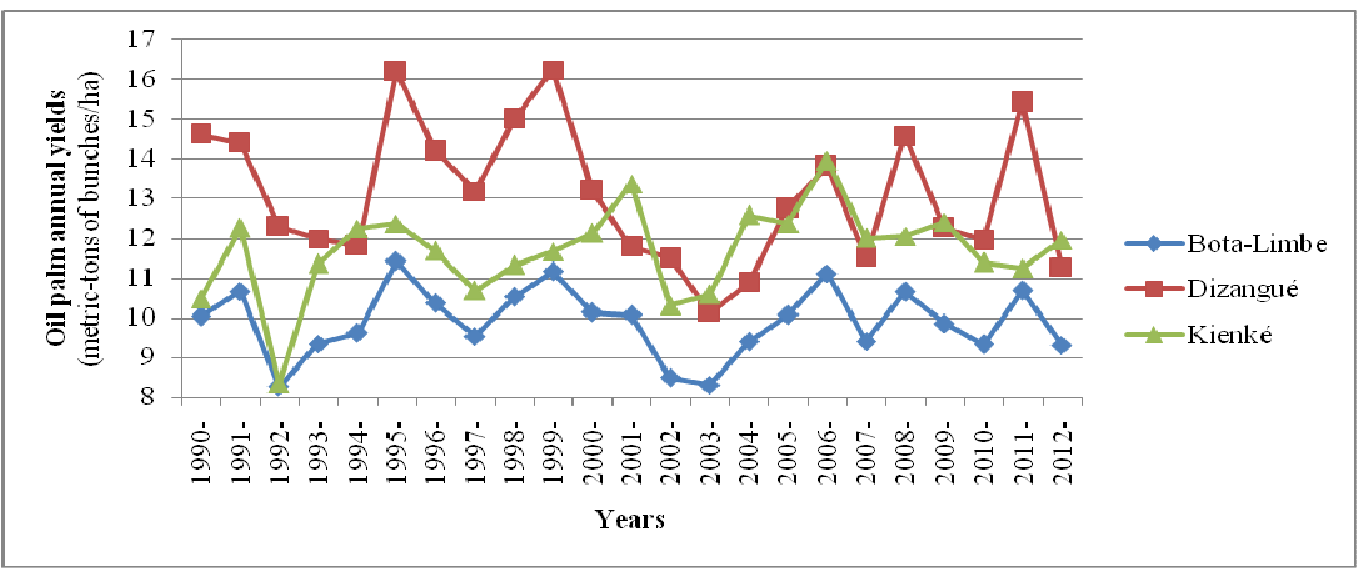

Figure 2: Oil palm annual yield variations over a 23-year-period (1990-2012) at Bota-Limbe (CDC), Dizangué (SAFACAM) and Kienké (SOCAPALM).

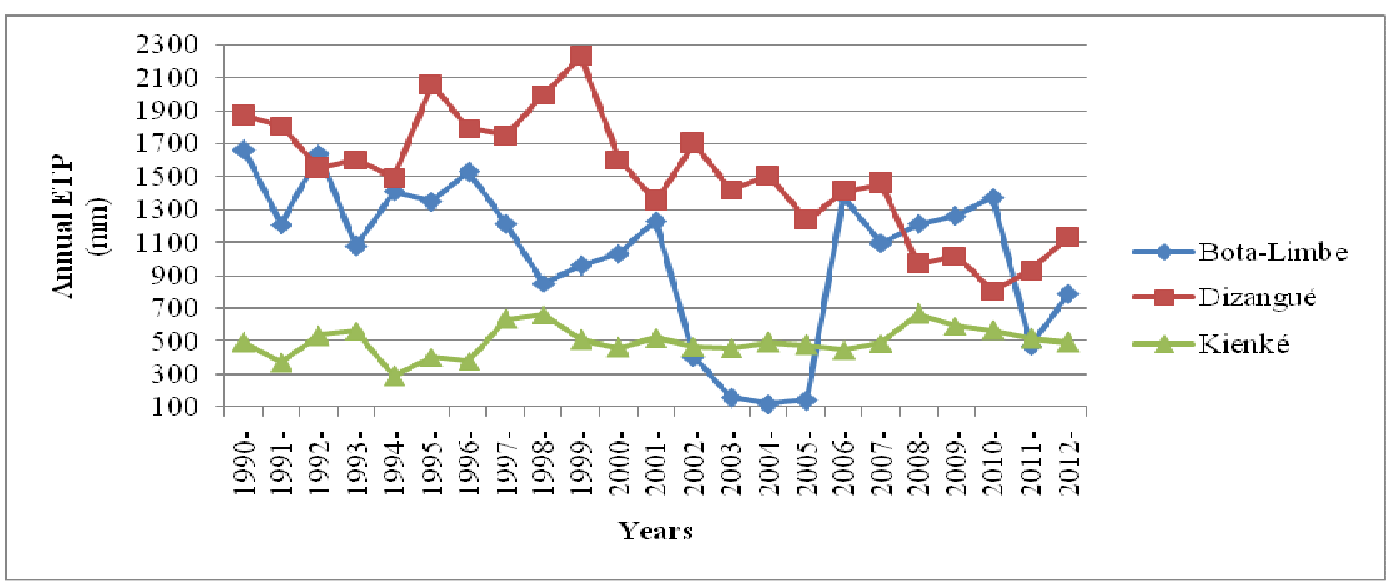

Figure 3: Annual ETP fluctuations over a 23-year-period (1990-2012) in Bota-Limbe, Dizangué and Kienké.

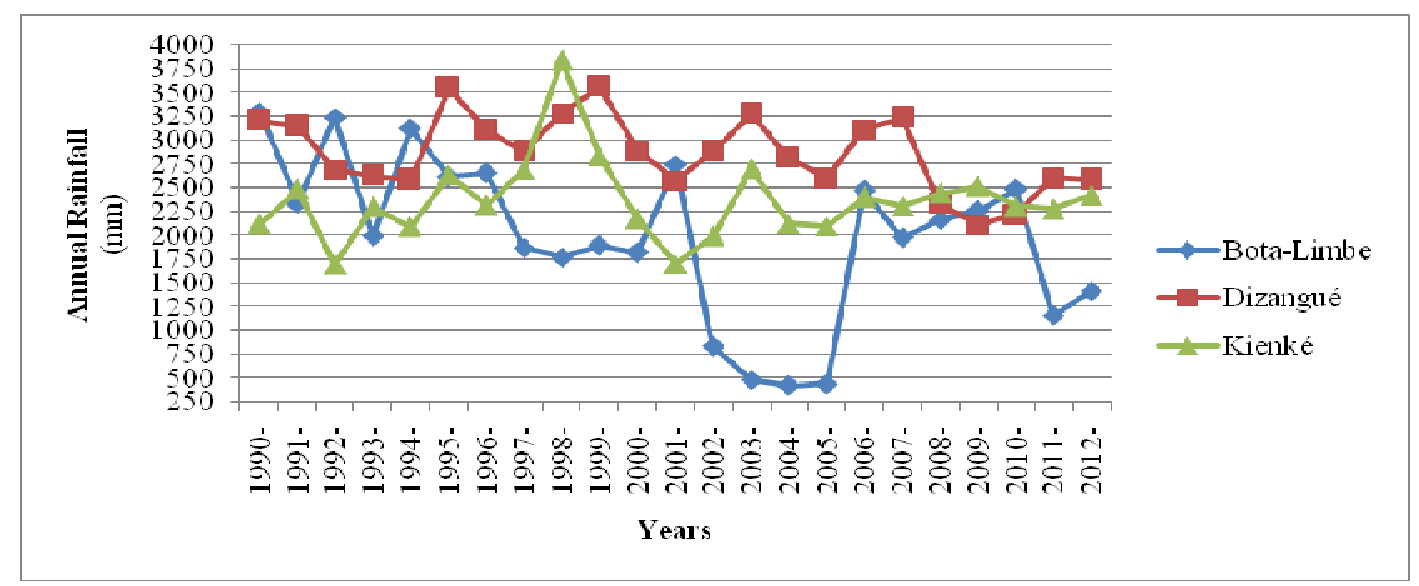

Figure 4: Annual rainfall fluctuations over a 23-year-period (1990-2012) in Bota-Limbe, Dizangué and Kienké. 


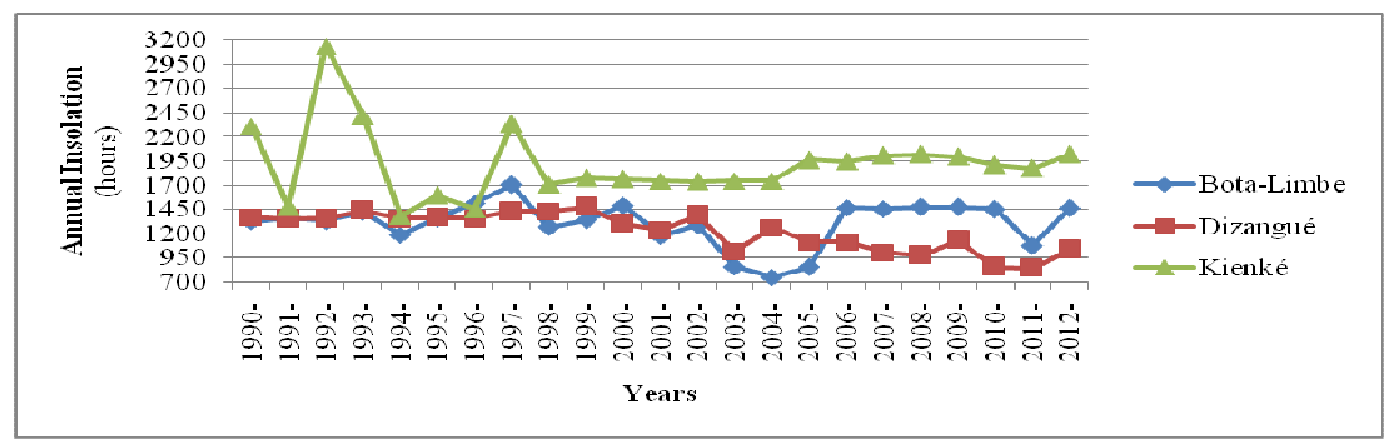

Figure 5: Annual insolation fluctuations over a 23-year-period (1990-2012) in Bota-Limbe, Dizangué and Kienké.

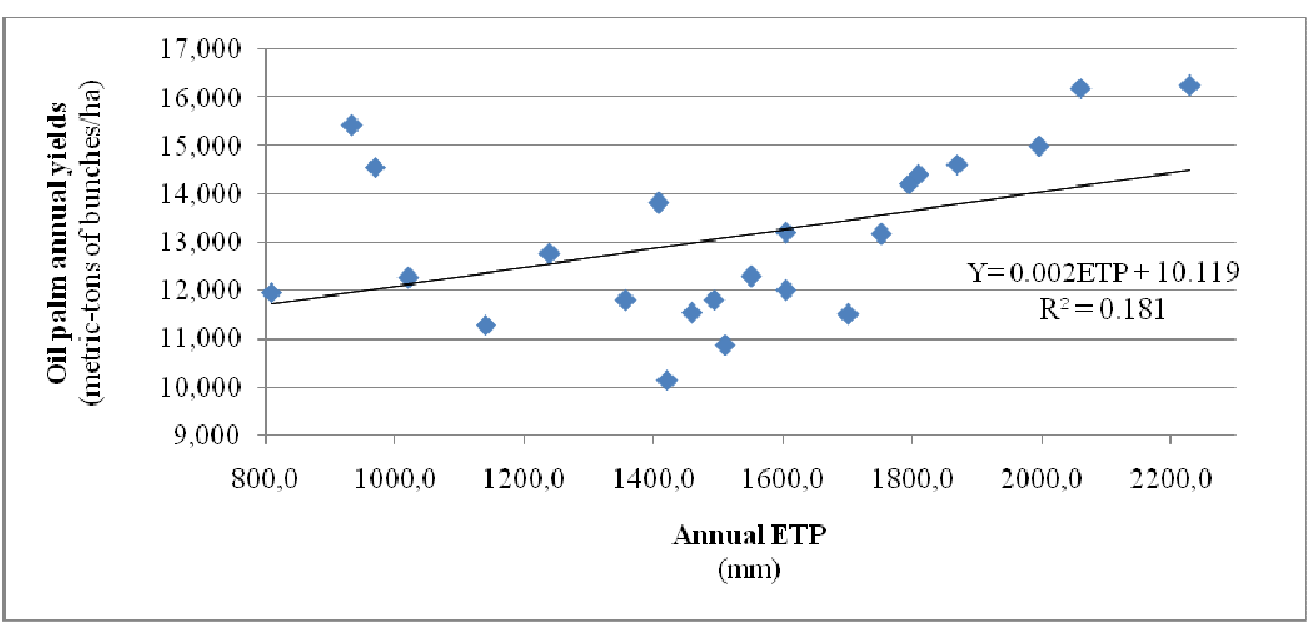

Figure 6: Relationship between oil palm annual yields and Annual ETP in Dizangué.

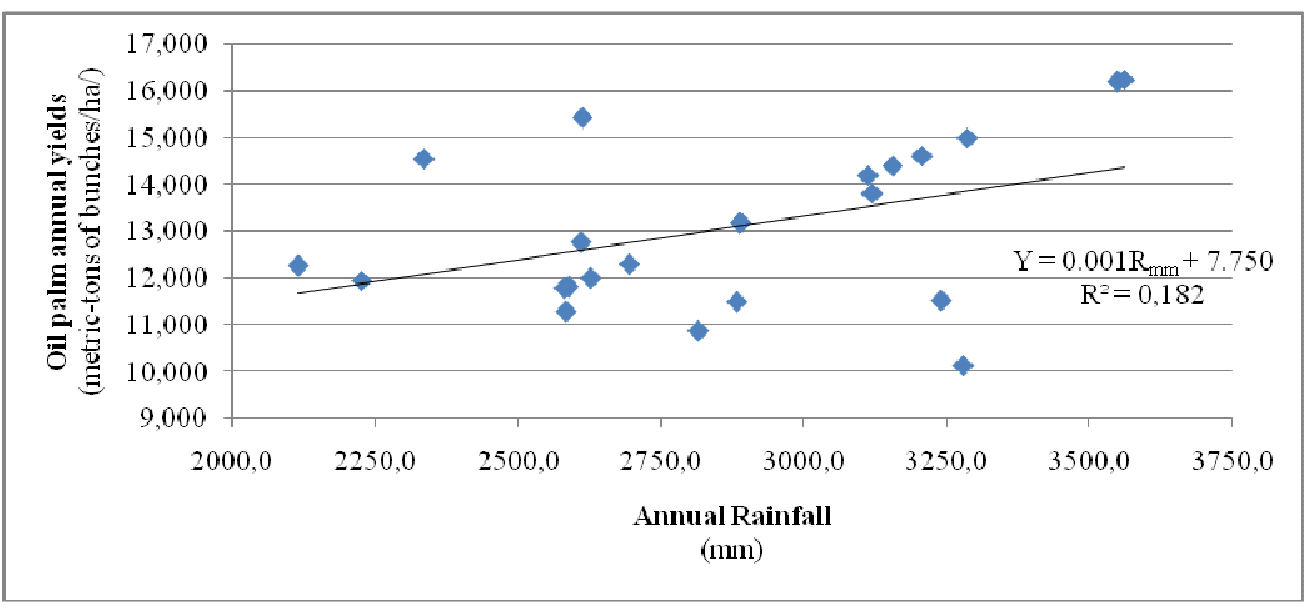

Figure 7: Relationship between oil palm annual yields and Annual rainfall in Dizangué. 
F. NKODO and Z. AMBANG / Int. J. Biol. Chem. Sci. 9(6): 2833-2846, 2015

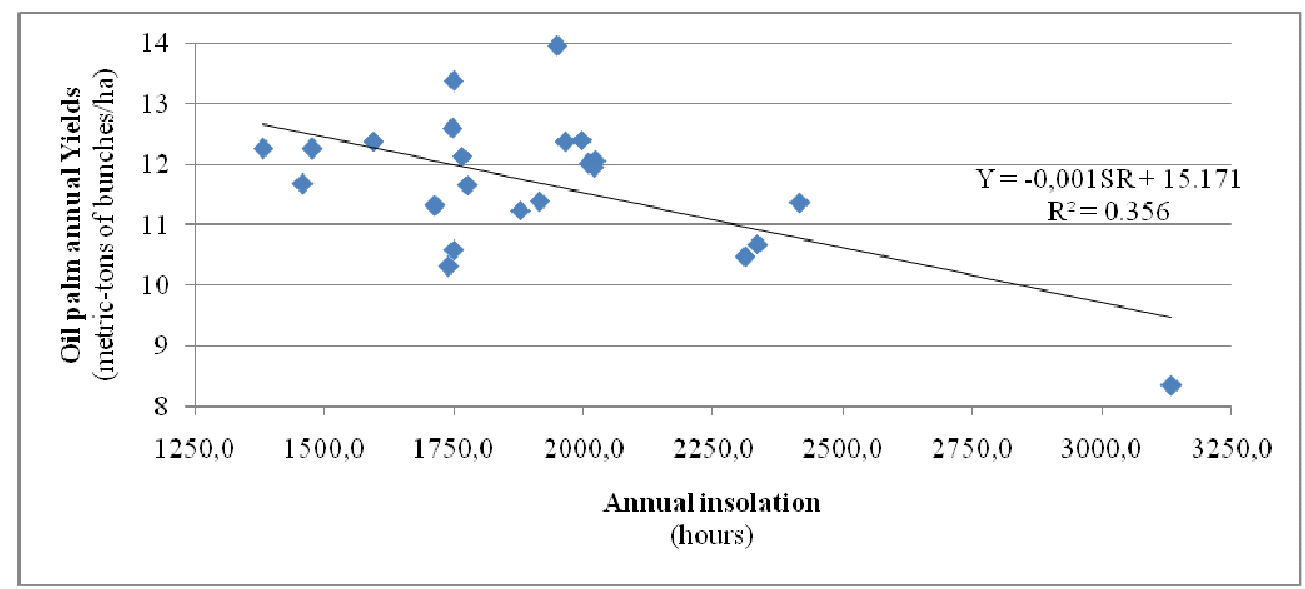

Figure 8: Relationship between oil palm annual yields and Annual insolation in Kienké.

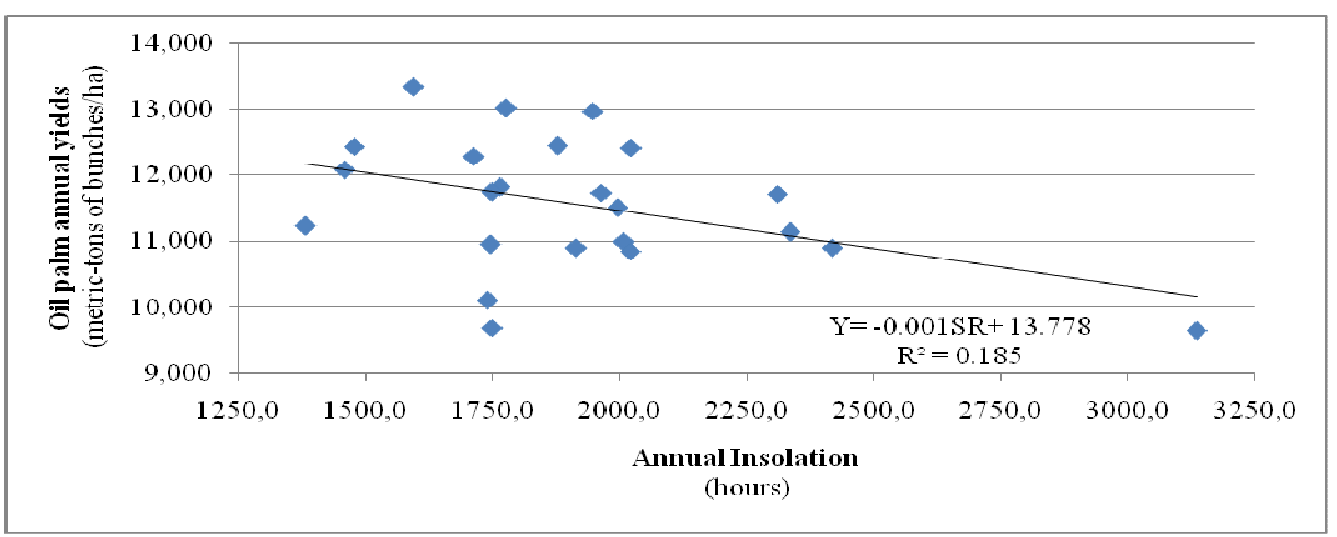

Figure 9: Relationship between oil palm annual yields and Annual insolation in a coastal zone's location " $\mathrm{x}$ ".

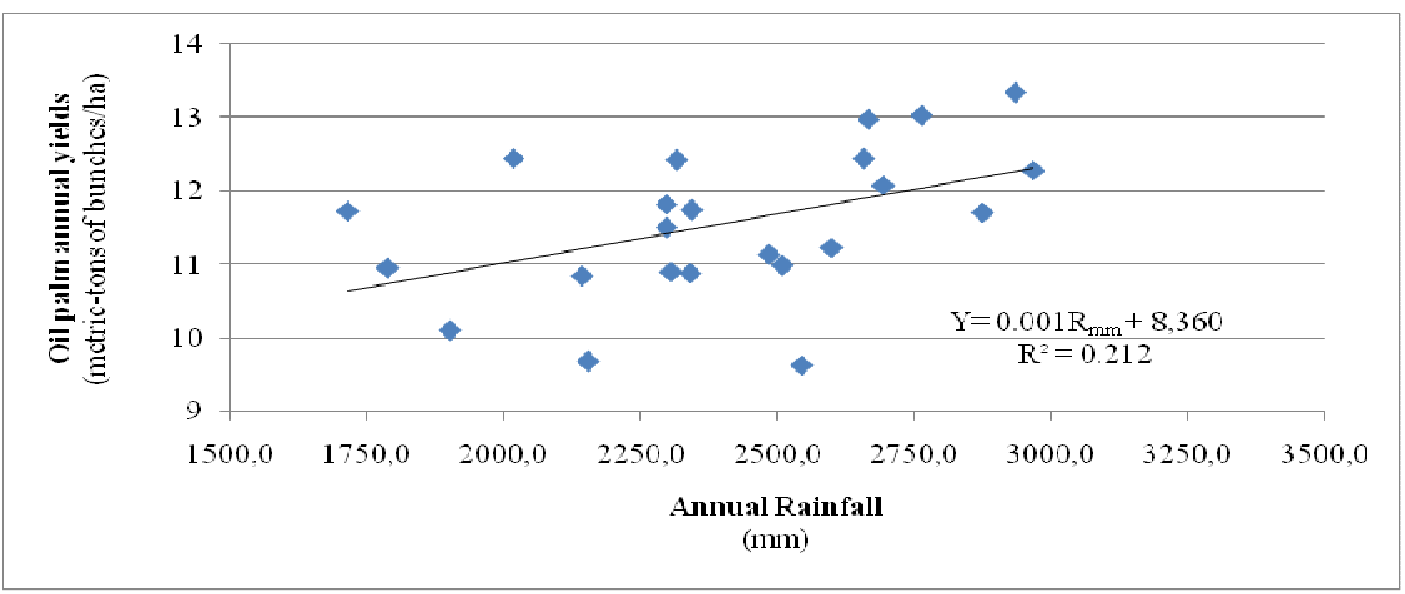

Figure 10: Relationship between oil palm annual yields and Annual rainfall in a coastal zone's location " $\mathrm{x}$ ". 
Table 1: ANOVA of effects of years, locations and field plots on oil palm annual yields.

\begin{tabular}{lrlrlll}
\hline $\begin{array}{l}\text { Sources } \\
\text { of variations }\end{array}$ & df & $\begin{array}{l}\text { Sum } \\
\text { of squares }\end{array}$ & \multicolumn{1}{l}{$\begin{array}{l}\text { Means } \\
\text { squares }\end{array}$} & $\mathbf{F}_{\text {cal }}$ & $\mathbf{F}_{\text {tab }}$ & Decision \\
$\begin{array}{l}\text { Main effects } \\
\text { Years }\end{array}$ & 22 & 334.641 & 15.210 & 12.315 & 1.835 & $* *$ \\
Locations & 2 & 586.646 & 293.323 & 237.508 & 4.000 & $* *$ \\
Field plots & 4 & 347.491 & 86.872 & 70.341 & 2.530 & $* *$ \\
Interactions & & & & & & \\
Years*locations & 44 & 234.907 & 5.543 & 4.488 & 1.566 & $* *$ \\
Years*field plots & 88 & 322.548 & 33.665 & 21.967 & 1.400 & $* *$ \\
Locations*field plots & 8 & 270.827 & 1.235 & 27.411 & 2.100 & $* *$ \\
Error & 176 & 217.377 & - & - & - & - \\
Total & 344 & 2323.437 & - & - & - & - \\
\hline$\quad * *$ very significant $(\mathrm{P}<0.01)$ & & & & &
\end{tabular}

Table 2: Separation of means of oil palm annual yields.

\begin{tabular}{|c|c|c|c|c|}
\hline \multirow[b]{2}{*}{$\begin{array}{l}\text { Year of } \\
\text { harvest }\end{array}$} & \multicolumn{4}{|c|}{$\begin{array}{c}\text { Average yields } \\
\text { (metric-tons of bunches/ha) }\end{array}$} \\
\hline & Bota-Limbe & Dizangué & Kienké & Whole \\
\hline 1990 & $10.045^{\text {ghijk }}$ & $14.261^{\text {cde }}$ & $10.471^{\mathrm{pqrs}}$ & 11.719 $^{\text {ghijklm }}$ \\
\hline 1991 & $10.664^{\text {bcde }}$ & $14.401^{\text {cdef }}$ & $12.259^{\text {cdefg }}$ & $12.441^{\text {bcde }}$ \\
\hline 1992 & 8.262 & $12.299^{\mathrm{ijklm}}$ & 8.355 & $9.638^{\mathrm{tu}}$ \\
\hline 1993 & $9.343^{\mathrm{mno}}$ & $11.939^{\mathrm{lmno}}$ & $11.365^{\mathrm{ijklmnop}}$ & $10.900^{\text {tu }}$ \\
\hline 1994 & $9.628^{\mathrm{ijklmn}}$ & $11.814^{\mathrm{lmnop}}$ & $12.257^{\text {cdefg }}$ & $11.233^{\mathrm{ijk}}$ \\
\hline 1995 & $11.434^{\mathrm{a}}$ & $16.202^{\mathrm{ab}}$ & $12.384^{\text {cde }}$ & $13.340^{\mathrm{a}}$ \\
\hline 1996 & $10.358^{\text {defg }}$ & $14.210^{\mathrm{defgh}}$ & $11.685^{\text {defghijklm }}$ & $\mathbf{1 2 . 0 8 4 ^ { \text { defgh } }}$ \\
\hline 1997 & $9.547^{\mathrm{jklmno}}$ & $13.180^{\mathrm{hijk}}$ & $10.689^{\mathrm{r}}$ & $11.139^{\mathrm{j} k \mathrm{lmno}}$ \\
\hline 1998 & $10.531^{\mathrm{defg}}$ & $15.000^{\mathrm{cd}}$ & $11.328^{\mathrm{ijklmnop}}$ & $\mathbf{1 2 . 2 8 7 ^ { \mathrm { defg } }}$ \\
\hline 1999 & $11.167^{\mathrm{ab}}$ & $16.253^{\mathrm{a}}$ & $11.665^{\mathrm{hijk} k m n o}$ & $13.028^{\mathrm{ab}}$ \\
\hline 2000 & $10.133^{\text {defghi }}$ & 13.198 & $12.139^{\mathrm{ijklmnop}}$ & $11.822^{\text {fghi }}$ \\
\hline 2001 & $10.068^{\text {ghijk }}$ & $11.789^{\mathrm{Imnopq}}$ & $13.377^{\text {cdefghi }}$ & $11.745^{\mathrm{hij}}$ \\
\hline 2002 & 8.487 & $11.500^{\mathrm{mnopqrs}}$ & $10.319^{\mathrm{ab}}$ & $10.102^{t}$ \\
\hline 2003 & 8.315 & $10.145^{\mathrm{u}}$ & $10.594^{\mathrm{opqr}}$ & $9.685^{\text {tu }}$ \\
\hline 2004 & $9.395^{\mathrm{mno}}$ & $10.875^{\text {qrstu }}$ & $12.594^{\mathrm{bc}}$ & $\mathbf{1 0 . 9 5 5 ^ { \text { mnopq } }}$ \\
\hline 2005 & $10.069^{\text {ghij }}$ & $12.759^{\mathrm{ijkl}}$ & $12.377^{\text {cdef }}$ & $11.735^{\text {ghijk }}$ \\
\hline 2006 & $11.121^{\mathrm{abc}}$ & 13.814 & $13.962^{\mathrm{a}}$ & $12.975^{\mathrm{abc}}$ \\
\hline 2007 & $9.416^{\mathrm{Imno}}$ & $11.526^{\mathrm{mnopqr}}$ & $12.015^{\text {cdefghijk }}$ & $\mathbf{1 0 . 9 8 6}^{\mathrm{mnop}}$ \\
\hline 2008 & $10.649^{\text {bcdef }}$ & 14.563 & $12.059^{\text {cdefghij }}$ & $12.424^{\text {bcdef }}$ \\
\hline 2009 & $9.861^{\mathrm{ijklmn}}$ & $12.260^{\mathrm{jklmn}}$ & $12.406^{\mathrm{cd}}$ & $11.509^{\mathrm{hijklm}}$ \\
\hline 2010 & $9.336^{\mathrm{mno}}$ & $11.951^{\mathrm{lmnop}}$ & $11.388^{\text {hijklmn }}$ & $10.892^{\text {nopqrs }}$ \\
\hline 2011 & $10.678^{\mathrm{bcd}}$ & $15.433^{\mathrm{abc}}$ & $11.248^{\mathrm{jklmnopq}}$ & $12.453^{\mathrm{bcd}}$ \\
\hline 2012 & $9.317^{\mathrm{mno}}$ & $12.284^{\mathrm{mnopqrst}}$ & $11.955^{\text {cdefghijkl }}$ & $\mathbf{1 0 . 8 5 2 ^ { \text { nopqrs } }}$ \\
\hline
\end{tabular}

Numbers in the same column followed by the same letter are not significantly different $(\mathrm{P}<0.05)$. Numbers followed by no letter are not significantly different. 


\section{DISCUSSION}

The results of the current study do not contradict those which were obtained by Piapang (2008) relating that oil palm productions recorded over many years in Kienké appeared to be significantly different. The results of this study are also in accordance with those which were disclosed by Nkoume (2011) who, after comparing years of harvest on the basis of oil palm yields (in metric-tons of bunches/ha) in Bota Palm Estate (CDC), came to the same conclusion of existing highly significant differences $(\mathrm{p}=0.001)$ between years of production. Bougna (2013), in a comparable study on oil palm in Dizangué, came also to the same conclusion.

It might be useful however to precise in which unit oil palm yields must be expressed. As a matter of fact, according to Henson and Mohd Tayeb (2001) and according to Henson (2007), oil palm yield in average weight of bunches is negatively correlated with oil palm yield in number of bunches, due to climatic factors. These authors have also pointed out in their respective works that maximum temperature is statistically significant and positively correlated with yield in weight of bunches 24 to 30 months before harvest and not during harvest.

Muhamad and Tsan (2008) have reported following some of their works that rainfall is strongly correlated with oil palm yield 18 months before harvest time because it favors the formation of female inflorescences; however, it becomes more and more feebly correlated with yield as harvest is getting closer. Likewise, Henson and Mohd Tayeb (2004) and Henson (2007) have found weak and not significant correlations for rainfall and insolation during time of harvests (with yields expressed in average tonnage of oil palm bunches).

The current study has not permitted to establish strong correlations, for those correlations which were found significant, between annual tonnages of bunches per hectare and yearly climatic variables. This result is in accordance with findings by Nkoume (2011) who, after determining partial correlation coefficients between yields and climatic variables in Bota Palm Estate (CDC), could find no significant correlation. In other words, no linear regression relationship established between a yield and a single climatic variable could significantly explain the yield buildups. Bougna (2013), in a comparable work in Dizangué, found only annual maximum temperature significantly correlated with yield $(\mathrm{r}=-0.22$ at $\mathrm{p}=0.02$; that is to say the annual maximum temperature effect being negative, when maximum temperature increases, yield decreases). Piapang (2008), as for him, found no climatic variable significantly correlated with annual oil palm yield in his work in Kienké. However, he would carry on his analyses to determine that annual rainfall (in $\mathrm{mm}$ ) has a very negative effect on annual tonnage of bunches per hectare. He would justify that phenomenon by explaining that an increase in rainfall leads to an important decrease in yields. He found, of all climatic variables he dealt with, rainfall could be the one contributing the most to yield buildups.

Piapang (2008) was successful in establishing a significant multiple linear regression relationship (up to $90 \%$ of prediction) between annual tonnages of oil palm bunches per hectare and the whole climatic variables. Although he found rainfall alone had an important effect (more than $52 \%$ ) on annual yields in simple linear regression equations, he discovered however it had no effect on annual yields in multiple linear regression equations. Piapang (2008) stated the hypothesis of an interaction among climatic factors in which some of them would mutually exclude each other. Bougna (2013) was not much successful in trying to establish simple or multiple linear regression relationships between oil palm yields and climatic variables. He got however a multiple linear regression relationship between oil 
palm yields (in annual tonnages of bunches per hectare) and two climatic variables only (maximum temperature and wind speed), with $\mathrm{R}^{2}=0.13$ at $\mathrm{p}=0.0008$. The relationship could explain only $13 \%$ of yields; however, it was highly significant $(\mathrm{P}<0.01)$.

Weak correlations of some major climatic parameters when taken alone, such as insolation and rainfall, or their lack in multiple linear regression equations could be surprising. However, according to Henson and Mohd Tayeb (2004) and Henson (2007), it is known oil palm yield is determined by the sex-ratio, rate of inflorescence abortion, number of bunches and average weight of bunches; rainfall and insolation would therefore have an important impact on the aforementioned characteristics; but not on average annual tonnages of bunches, as it was the case in this study.

\section{Conclusion}

It has been given evidence in this study that there is a very significant year effect $(\mathrm{P}<0.01)$ on oil palm production in the coastal zone of Cameroon. The effect of a particular year on oil palm production results from climatic factors that acted during the year of harvest and during the previous two or three years. However, effects equally highly significant $(\mathrm{P}<0.001)$ of locations and field plots, as well as their interactions, make one believe other annual factors than the climate have had an influence on the determination of annual oil palm yields.

Correlation analyses have shown that only a few climatic variables (annual $\mathrm{R}_{\mathrm{mm}}$ and annual ETP) were significantly $(\mathrm{P}<0.05)$ or very significantly $(\mathrm{P}<0.01)$ correlated during the period observed (1990-2012) with oil palm annual tonnage per hectare.

Significant $(\mathrm{P}<0.05)$ or very significant $(\mathrm{P}<0.01)$ simple or multiple linear regression relationships between oil palm annual tonnage per hectare and a few yearly climatic variables were established; they contributed to explain yields from 18.10 to $54.60 \%$. Also, no significant multiple linear regression relationship could be established between oil palm annual yields (in metric-tons of bunches/ha/year) and all the yearly climatic variables taken together in none of the coastal zone locations studied.

Linear regressions might not be sufficient to explain completely all the yield variations. Other mathematical relationships for more accurate predictions must be built, as for example curvilinear regressions; for linear regressions may not be sufficient to explain annual yields in their completeness.

\section{COMPETING INTEREST}

The authors declare that they have no competing interest.

\section{AUTHORS' CONTRIBUTIONS}

This work was carried out in collaboration between both authors. FN designed the study, wrote the protocol, managed the literature searches, supervised the data collection, performed the statistical analysis and wrote the first draft of the manuscript. ZA realized the presentation of data through use of figures and tables and edited the final document. Both authors read and approved the final manuscript.

\section{ACKNOWLEDGEMENTS}

We thank the following persons for facilitating our search for crop and weather data from records of their respective plantations: $\mathrm{Mr}$ Jean Pierre CHARBON, Director General of SAFACAM, and his collaborators Mr Pierre ALLARD, Mr Simon HAGELSTEIN and Mr François MINSIER; Mr Jean François PAJOT, Director of the Agricultural operations and Acting Coordinator of the SOCALM Unit in Kienké, and his collaborators Mr Janvier OUM and $\mathrm{Mr}$ Gabain PONSU; Mr Raphaël TAM KATTA, Director of the Agricultural exploitations of HEVECAM, and his collaborator Mr Claude Martau DJONMAILA KOTWE; and $\mathrm{Mr}$ 
Joseph EKAMBI, Acting Coordinator of the CDC Unit at Bota-Limbe.

Our special appreciation goes to our former students for helping in collecting the data and in running the first analyses as part of their academic assignments: Mr Jean-Paul PIAPANG and $\mathrm{Mr}$ Augustin BOUGNA DIPANDA (FAAS, University of Dschang, Cameroon); Mr Verlain ONDO OMEME and $\mathrm{Mr}$ Dimitri NKOUME MBA (INSAB, University of Masuku in Franceville, Gabon).

\section{REFERENCES}

Akoua A.D. 2005. Utilisation des analyses des sols et des feuilles dans l'orientation de la fertilisation du palmier à huile au Cameroun: cas du périmètre de Dizangué dans la province du Littoral. Mémoire de fin d'études. FASA, UDs. $67 \mathrm{p}$.

Anonyme. 2001. Rapport économique et financier. AGRI-STAT $\mathrm{n}^{\text {os }}$ 3-9. MINAGRI, Yaoundé. 321 p.

Anonyme. 2007. Audit environnemental du complexe agro-industriel HEVECAM. HEVECAM, Niété. Cameroun. 926 p.

Anonyme. 2010. Zone côtière du Cameroun : situation socio-environnementale et perspectives de développement. Rapport d'activités 2010. MINEPDED, Yaoundé. $88 \mathrm{p}$.

Bell J.M. 2000. Rapport final du séminaireatelier sur le thème : Pour l'élaboration d'une stratégie de recherchedéveloppement à moyen et long terme sur le palmier à huile au Cameroun. Ministère de la Recherche et de l'Innovation. Yaoundé, Octobre 2000.

Bougna D.A. 2013. Incidence de la fluctuation des facteurs climatiques et du déficit hydrique sur les productions d'hévéa (Hevea brasiliensis Arg. Mull.) et du palmier à huile (Elaeis guineensis Jacq.) dans la région du Littoral: cas de la SAFACAM à Dizangué. Mémoire de diplôme d'ingénieur agronome. FASA, UDs. 81 p.
Corley R.H.V. 2001. Oil palm. Ecosystems of the World, 19: 299-320.

Corley R.H.V.; Tinker P.B. 2003. The Oil Palm. 4th edn. Oxford: Blacwell Science.

Henson I.E. 2007. Modelling the effects of physiological and morphological characters on oil palm growth and productivity. Oil palm Bulletin 54: 1-26.

Henson I.E.; Mohd Tayeb D. 2004. Seasonal variation in yield and development processes in an oil palm density trial on a peat soil. I. Yield and bunch number components. Journal of Oil palm Research 16: 88-105.

Julien-François G. 2008. Résistances contre deux géants industriels en forêt tropicale; populations locales versus plantations commerciales d'hévéas et de palmiers à huile dans le Sud-Cameroun. Uruguay. Hersilia Fonseca : Mouvement Mondial pour les Forêts Tropicales. Récupéré de la page Web http://www.wrm.org.uy. Juillet 2012.

Muhamad R.A.; Tsan T.Y. 2008. Rainfall impact on oil palm production and $\mathrm{O} E$ $\mathrm{R}$ at Telda Triang 2, Faculty of Applied Science, University Teknologi Mara. 74 p.

Mvondo-Ze A.D. 2008. Sols du Cameroun. Laboratoire des Sciences du sol et de l'Environnement, Département des sciences du sol, FASA, UDs, Cameroun. $10 \mathrm{p}$.

Nkodo F. 2014. Itinéraires technicoéconomiques de fertilisation des cultures. Seminaire-atelier de concertation et de formation des AgroDealers sur le système d'information des marchés et le marketing dans le soussecteur engrais. Organisé par le PRSSE/MINADER. Douala, Avril 2014.

Nkoume M. D. 2011. Contribution pour une meilleure estimation des productions théoriques de l'hévéa (Hevea brasiliensis Müll. Arg.) et du palmier à huile (Elaeis guineensis Jacq.) sur la 
base des données climatiques: cas des plantations de la CDC à Bota-Limbe, Région du Sud-Ouest Cameroun. Mémoire de diplôme d'ingénieur agronome. INSAB, Université des Sciences et Techniques de Masuku, Franceville, Gabon. 69 p.

Piapang J.P. 2008. Incidence de la fluctuation des facteurs climatiques et du déficit hydrique sur la production du palmier à huile (Elaeis guineensis Jacq.) dans la zone de forêt humide: cas de Kienke (Sud-Cameroun). Mémoire de diplôme d'ingénieur agronome, FASA, UDs, Cameroun. 58p.

Yana B. 2008. Evaluation biophysique et gestion de la fertilité pour les cultures d'hévéa, palmier à huile, manioc et maïs : cas des terres d'extension de la SAFACAM à Dizangué. Mémoire de diplôme d'ingénieur agronome. FASA, UDs, Cameroun. 62 p. 